\title{
Rapid hormonal regulation of $N$-acetylglucosamine transferase I
}

\section{F F Bolander Jr}

Department of Biological Sciences, University of South Carolina, Columbia, South Carolina 29208, USA; Email: Bolander@sc.edu

\begin{abstract}
Previous studies have shown that, in unstimulated mammary epithelial cells from virgin mice, prolactin receptors are retained intracellularly because of their incomplete $N$-glycosylation. Activation of the nitric oxide/cGMP pathway stimulates $N$ acetylglucosamine (NAG) transferase I activity, completion of terminal glycosylation, and redistribution of the receptors to the cell surface. In this study, it was shown that nitric oxide could stimulate the phosphorylation of NAG transferase I in intact cells and that the cGMP-dependent protein kinase (PKG) could directly phosphorylate the purified
\end{abstract}

enzyme. Furthermore, this modification was associated with enhanced enzymatic activity. Conversely, this stimulation of activity was blocked in intact cells by coincubation with a PKG inhibitor and reversed in the immunoprecipitated enzyme by alkaline phosphatase treatment. Kinetic analysis revealed that this effect on enzyme activity was due to an increase in $V_{\max }$ without any change in $K_{\mathrm{m}}$. Therefore, it appears that the nitric oxide/cGMP pathway activates NAG transferase I via direct phosphorylation by PKG.

Fournal of Molecular Endocrinology (2000) 24, 377-382

\section{INTRODUCTION}

In this laboratory it has previously been shown that, in resting mouse mammary epithelium, the majority of prolactin receptors are retained intracellularly in a partially glycosylated state (Bolander 1999). In particular, this post-translational modification appears to be arrested at the $N$-acetylglucosamine (NAG) transferase I step. However, the nitric oxide/cGMP signaling pathway rapidly shifts the prolactin receptor to the cell surface by stimulating the activity of this enzyme, which then completes terminal glycosylation. It was the purpose of this study to investigate the mechanism responsible for NAG transferase I regulation by nitric oxide/cGMP.

cGMP has three major targets: a protein kinase (protein kinase G, PKG), phosphodiesterases and ion channels (Schmidt et al. 1993). The stimulatory effect of cGMP on some phosphodiesterases is simply a mechanism for feedback inhibition and/or cross-talk with the cAMP pathway. The effect on cation channels could produce an increase in intracellular calcium, a known activator of nitric oxide synthase activity; this represents a positive feedback loop that would amplify the cGMP signal, rather than a primary effect. Therefore the most likely primary output of cGMP in the mammary gland is PKG. As there is a PKG consensus phosphorylation site in the sequence of mouse NAG transferase I (Pownall et al. 1992), it was of interest to determine if nitric oxide/cGMP could induce the acute phosphorylation of this enzyme in cell culture, if $\mathrm{PKG}$ could directly phosphorylate this enzyme, and if this modification had any effect on enzyme activity.

\section{MATERIALS AND METHODS}

\section{Materials}

Hepes, Tris, phenylmethylsulfonyl fluoride (PMSF), dithiothreitol (DTT), EDTA, sodium pyrophosphate, Tween 20, Triton X-100, 4-chloronaphthol, phosphotungstic acid, ovalbumin, bovine serum albumin (BSA), goat antirabbit antibody, adenosine $5^{\prime}$ triphosphate (ATP), guanosine- $3^{\prime}, 5^{\prime}$-cyclic monophosphate (cGMP), PKG (10 $200 \mathrm{U} / \mu \mathrm{g})$, alkaline phosphatase $(2400 \mathrm{U} / \mathrm{mg})$, UDP- $N$-acetylglucosamine (UDP-NAG) and UDP- $N$-acetyl-[6- $\left.{ }^{3} \mathrm{H}(\mathrm{N})\right]$ glucosamine $(60 \mathrm{Ci} / \mathrm{mmol})$ were purchased from Sigma Chemical Company (St Louis, MO, USA). Nitrocellulose paper, goat antirabbit antibody conjugated 
to horseradish peroxidase, acrylamide, bisacrylamide, prestained low-range molecular weight standards, and all other reagents for sodium dodecyl sulfate (SDS) electrophoresis were obtained from Bio-Rad Laboratories (Hercules, CA, USA). Phosphate buffered saline (PBS) and Medium 199 with Earle's salts were from Grand Island Biological Company (Grand Island, NY, USA); collagenase type I (179 U/mg) was purchased from Worthington Biochemicals (Freehold, NJ, USA). Sodium nitroprusside was from Alexis Corporation (San Diego, CA, USA) and 8-bromoguanosine3',5'-cyclic monophosphorothioate, Rp-isomer (a PKG inhibitor, PKGI) was purchased from BioLog Life Science (Bremen, Germany). X-Omat AR $\mathrm{X}$-ray film was obtained from Eastman Kodak (Rochester, NY, USA). $\left.{ }^{32} \mathrm{P}\right]$ Orthophosphoric acid $(8500 \mathrm{Ci} / \mathrm{mmol})$ and $\left[\gamma^{32} \mathrm{P}\right]$-adenosine $5^{\prime}$ triphosphate $\left(\left[{ }^{32} \mathrm{P}\right] \mathrm{ATP} ; 3000 \mathrm{Ci} / \mathrm{mmol}\right)$ were from New England Nuclear (Boston, MA, USA).

\section{Cell culture}

Virgin mice $(\mathrm{C} 3 \mathrm{H} / \mathrm{HeN})$ were obtained from the Frederick Cancer Research Facility (Frederick, MD, USA). The mice were killed by cervical dislocation and an epithelial cell-enriched fraction was isolated from mammary glands as previously described (Vonderhaar et al. 1973). Cells were cultured for $30 \mathrm{~min}$ at $37^{\circ} \mathrm{C}$ in Medium 199 containing $20 \mathrm{mM}$ Hepes $(\mathrm{pH} 7 \cdot 6)$ and combinations of the following reagents as required by the individual experiment: sodium nitroprusside $(100 \mu \mathrm{g} / \mathrm{ml})$ and PKGI $(250 \mu \mathrm{M})$. When proteins were to be labeled in intact cells, cells were equilibrated overnight with $\left[{ }^{32} \mathrm{P}\right]$ orthophosphoric acid $(50 \mu \mathrm{Ci} / \mathrm{ml})$ before the $30-\mathrm{min}$ incubation.

\section{$N$-Acetylglucosamine transferase I activity}

NAG transferase I was measured by the method of Vischer \& Hughes (1981). Briefly, mammary epithelial cells were homogenized or immunoprecipitates suspended in $50 \mathrm{mM}$ sodium phosphate buffer (pH 6.9) containing $10 \mathrm{mM} \mathrm{KCl}, 5 \mathrm{mM}$ $\mathrm{MgCl}_{2}, 5 \mathrm{mM} \mathrm{MnCl}_{2}, 5 \mathrm{mM}$ pyrophosphate, $0 \cdot 1 \%$ Triton X-100 and $2 \mu \mathrm{M}$ PMSF. UDP- $N$-acetyl$\left[{ }^{3} \mathrm{H}\right]$ glucosamine and ovalbumin were added to the reaction mixture to give a final concentration of $1 \mathrm{mM}$ and $4 \mathrm{mg} / \mathrm{ml}$, respectively, in a final volume of $0.5 \mathrm{ml}$. After $2 \mathrm{~h}$ at $37^{\circ} \mathrm{C}$, the labeled ovalbumin was precipitated by $1 \mathrm{ml} 1 \%$ phosphotungstic acid in $0.5 \mathrm{M} \mathrm{HCl}$, washed with $1 \mathrm{ml}$ ice-cold $95 \%$ ethanol and dissolved in $0.5 \mathrm{ml} 0.5 \mathrm{M} \mathrm{NaOH}$. After neutralization, scintillation fluid was added and the samples counted. When enzyme kinetics were performed the ovalbumin substrate concentration was varied, the incubation period shortened to $30 \mathrm{~min}$ in order to obtain initial reaction rates, and the specific activity of the UDP- $N$-acetyl$\left[{ }^{3} \mathrm{H}\right]$ glucosamine doubled in order to obtain measurable radioactive incorporation during the shorter incubation period. Eadie-Hofstee plots were performed in quadruplicate.

\section{Antibody production and characterization}

A peptide with a sequence corresponding to the linker region of mouse NAG transferase I (residues 31-50; Pownall et al. 1992) was synthesized by Genemed Synthesis (South San Francisco, CA, USA). This peptide was then coupled to limpet hemocyanin and used as an antigen to generate polyclonal antibodies in New Zealand albino rabbits by the Monoclonal Antibody Laboratory at the University of South Carolina (Columbia, $\mathrm{SC}$, USA). The resulting antiserum was immunoadsorbed with hemocyanin before use.

Samples for western blots were subjected to SDSPAGE according to the method of Laemmli (1970) and immunoblotted using the method of Hawkes et al. (1982). Briefly, samples were separated on a $13 \mathrm{~cm}$ slab gel containing $12 \cdot 5 \%$ acrylamide after being concentrated on a stacking gel of 5\% acrylamide. After the proteins were transferred to nitrocellulose, the paper was deblocked in PBS containing 3\% BSA, rinsed in PBS and incubated overnight with the NAG transferase I antibody (1:1000 in PBS with 1\% BSA). After rinsing in PBS, the nitrocellulose was incubated with goat antirabbit antibody conjugated to horseradish peroxidase (1:1000 in PBS with $1 \% \mathrm{BSA}$ ) for $1 \mathrm{~h}$, rinsed twice in PBS with $0.05 \%$ Tween 20 and once in PBS. Bands were visualized by placing the paper in a solution of 4-chloronaphthol $(2.4 \mathrm{mg} / \mathrm{ml})$ and hydrogen peroxide $(60 \mu \mathrm{l} 30 \%$ solution in $100 \mathrm{ml}$ PBS). All of these procedures were performed at room temperature. Densitometry readings were used to adjust samples to identical enzyme concentrations for subsequent experiments.

\section{Radiolabeling of proteins}

Proteins in intact cells were labeled as described above (Cell culture). The labeling of purified proteins was performed on NAG transferase I immunoprecipitated by the method of Ono \& Oka (1980) except that the buffers contained $5 \mathrm{mM}$ pyrophosphate, a general phosphatase inhibitor. Half of the immunoprecipitated enzyme was incubated with unlabeled ATP, as described below, and assayed for enzyme activity. The other half was incubated with $\left[{ }^{32} \mathrm{P}\right] \mathrm{ATP}$ and used to determine the 

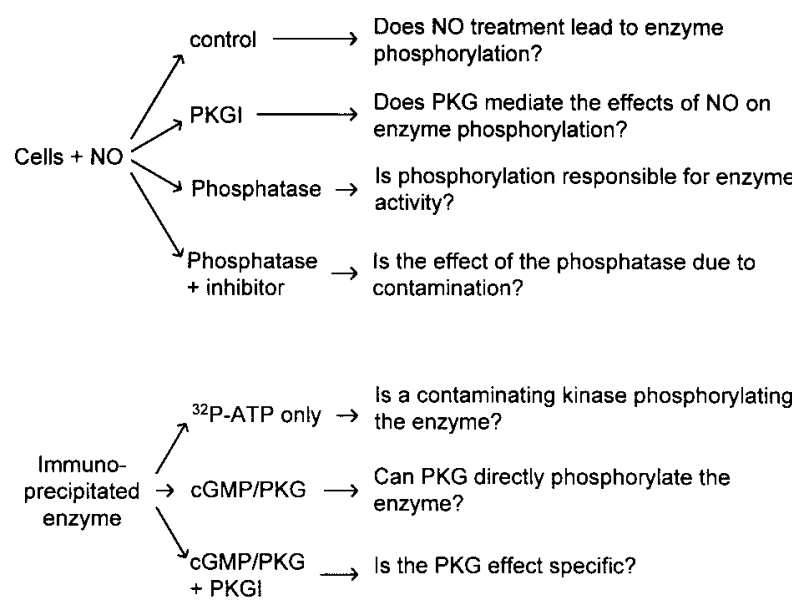

FIGURE 1. A summary of the experiments in this paper and their rationale. $\mathrm{NO}$, nitric oxide.

incorporation of phosphorus-32. Briefly, the immunoprecipitate was suspended in $0.1 \mathrm{ml} 50 \mathrm{mM}$ Tris- $\mathrm{HCl}$ (pH 7.5), $10 \mathrm{mM} \mathrm{MgCl}_{2}, 2 \mathrm{mM}$ DTT, $0.2 \mathrm{mM}$ EDTA, $5 \mathrm{U}$ PKG , $0.5 \mu \mathrm{mol} \mathrm{cGMP}$, and $0.2 \mathrm{mM}$ ATP or $\left[{ }^{32} \mathrm{P}\right]$ ATP $(1000$ c.p.m./pmol). Parallel samples were incubated without PKG and cGMP and used as controls for contaminating kinases. All samples were incubated at $37^{\circ} \mathrm{C}$ for $30 \mathrm{~min}$, after which the immunoprecipitates were washed.

Dephosphorylation of the labeled enzyme was accomplished by alkaline phosphatase. Briefly, NAG transferase I immunoprecipitated from nitric oxide-stimulated cells was suspended in $0 \cdot 1 \mathrm{ml} 75 \mathrm{mM}$ Tris-HCl (pH 9.0). To half of each sample, $5 \mathrm{U}$ alkaline phosphatase were added; the other half also included $5 \mathrm{mM}$ pyrophosphate as a control for specificity. Both halves were incubated at $37^{\circ} \mathrm{C}$ for $30 \mathrm{~min}$, after which the reaction was stopped by the addition of $1 \mu \mathrm{l} 1 \mathrm{M}$ DTT and the immunoprecipitates were washed. Enzyme activity was then measured as described above.

Incorporation of phosphorus-32 was assessed by SDS gel electrophoresis as described for western blots, except that the immunoprecipitates were dissociated in $4 \mathrm{M}$ urea before loading onto the gels and after electrophoresis the gels were dried and exposed to Kodak X-Omat AR film for 1-3 days at $-70{ }^{\circ} \mathrm{C}$. Western blots were performed in quadruplicate.

A summary of these experiments and their rationale is given in Fig. 1.

\section{RESULTS}

The specificity and efficacy of the antiserum were determined by SDS gel electrophoresis and enzyme

www.endocrinology.org

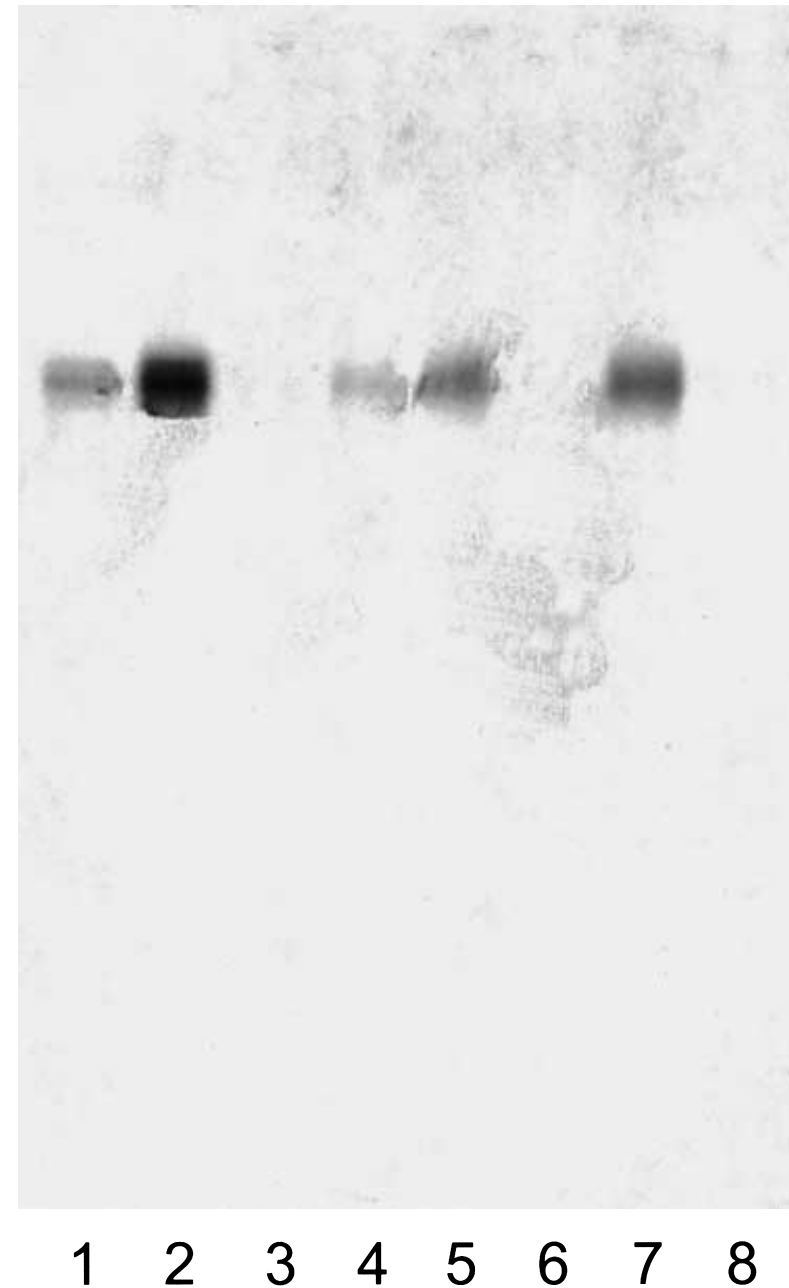

FIGURE 2. A representative autoradiograph of immunoprecipitated, ${ }^{32}$ P-labeled NAG transferase I. Lanes 1-5: cells were cultured with $\left[{ }^{32} \mathrm{P}\right]$ orthophosphoric acid without additives (lane 1 ), with sodium nitroprusside (lanes 2, 4 and 5), or with sodium nitroprusside and a PKG inhibitor (PKGI, lane 3). NAG transferase I immunoprecipitated from nitric oxide-exposed cells was treated with alkaline phosphatase (lane 4) or with phosphatase and a phosphatase inhibitor (lane 5). Lanes 6-8: cells were cultured without additives. Immunoprecipitated NAG transferase I was incubated with $\left[{ }^{32} \mathrm{P}\right] \mathrm{ATP}$ alone (lane 6), with cGMP/PKG (lane 7), or with cGMP/PKG and PKGI (lane 8).

Approximately equal amounts of enzyme were applied to each lane.

assays. The rabbit antimouse NAG transferase I antibody detected a single band with a molecular mass of $52.3 \mathrm{kDa}$ (Fig. 2), which compares favorably with the theoretical value of $50.5 \mathrm{kDa}$ (Pownall et al. 1992). In addition, the antiserum 
precipitated more than $95 \%$ of the enzymatic activity from homogenates (data not shown).

NAG transferase I appeared to be basally phosphorylated (Fig. 2, lane 1) and this modification increased dramatically after the cells had been exposed to nitric oxide (lane 2). This effect appears to be mediated by PKG, as it was blocked by a specific PKGI (lane 3). In addition, the label could be partially removed from the immunoprecipitated enzyme by alkaline phosphatase (lane 4) and this dephosphorylation was blocked by a phosphatase inhibitor (lane 5).

Although these experiments implicate $\mathrm{PKG}$ in the regulation of NAG transferase I, they do not provide evidence for a direct modification of the enzyme. Although this glycosylating enzyme does have a phosphorylation consensus site for PKG, anchoring proteins and molecular scaffolds can compartmentalize kinases, thereby limiting their access to potential substrates (Schillace \& Scott 1999). For example, it is possible that the observed phosphorylation was the result of a protein kinase cascade initiated by PKG; such a cascade leading from cGMP/PKG to mitogen-activated protein kinase has been demonstrated in several tissues (Callsen et al. 1998, Ho et al. 1999). Therefore the ability of PKG to label the purified enzyme was investigated. No labeling occurred in the presence of $\left[{ }^{32} \mathrm{P}\right] \mathrm{ATP}$ when PKG was omitted from the reaction mixture, indicating that no contaminating kinases were coprecipitated with NAG transferase I (Fig. 2, lane 6). PKG was able to phosphorylate the enzyme directly (lane 7), and this labeling was markedly reduced by the simultaneous presence of a PKGI (lane 8), demonstrating the specificity of the phosphorylation.

To determine if this modification had any effect on NAG transferase I activity, split samples were subjected to enzyme assays (Fig. 3). There was a good correlation between enzyme phosphorylation and activity under all circumstances. In particular, NAG transferase I activities were increased in enzymes labeled either in intact cells or in purified proteins and were reduced in enzymes the phosphorylation of which was either blocked by a PKGI or removed by alkaline phosphatase.

In order to analyse the mechanism for this enhanced enzyme activity, Eadie-Hofstee plots were generated (Fig. 4). In these graphs, $V_{\max }$ is obtained from the $X$-intercept and $K_{\mathrm{m}}$ from the slope $\left(m=-1 / K_{\mathrm{m}}\right) . \quad K_{\mathrm{m}}$ for ovalbumin did not differ significantly between the control and nitric oxidetreated cells: $31 \pm 7 \mu \mathrm{M}$ and $38 \pm 7 \mu \mathrm{M}$ respectively (means \pm s.E. for six determinations). However, $V_{\max }$ of the NAG transferase I immunoprecipitated

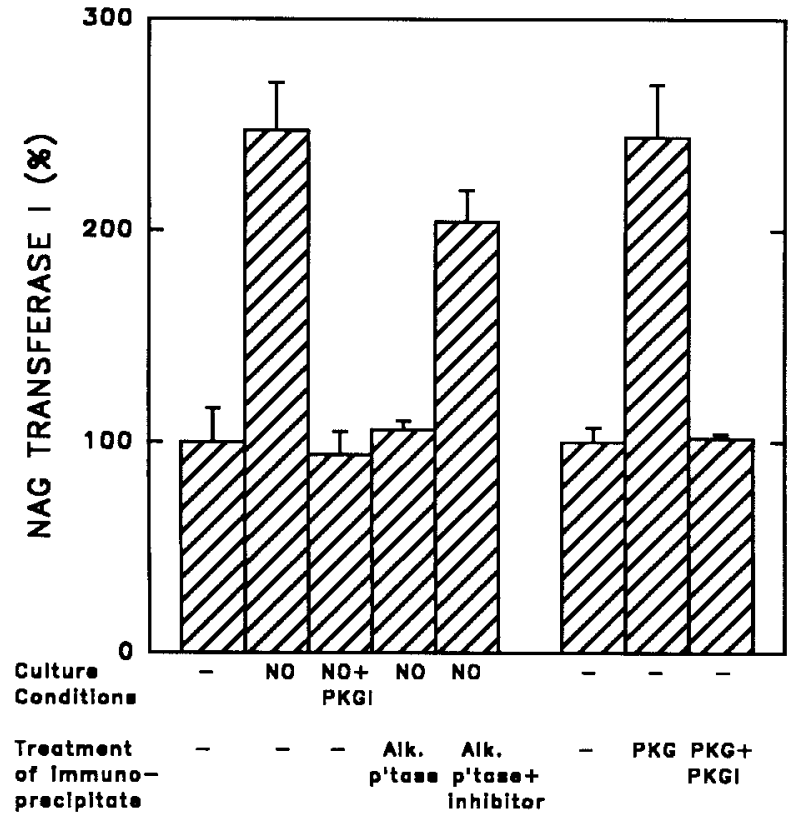

FIGURE 3. Correlation of NAG transferase I activity with the phosphorylation status of the enzyme. Columns correspond to lanes 1-8 in Fig. 2. Mammary epithelial cells were cultured without additives or with combinations of sodium nitroprusside (nitric oxide, $\mathrm{NO}$ ) and a PKGI, as noted below the $X$-axis. Some of the immunoprecipitates were subsequently treated with either alkaline phosphatase (Alk. p'tase) or cGMP/PKG, with or without their respective inhibitors. Means \pm s.E. are given for six determinations.

from the nitric oxide-treated cells was twice that for the enzyme from control cells: $4 \cdot 3 \pm 0.4 \mu \mathrm{mol} /$ $\mathrm{min} \cdot \mathrm{mg}$ enzyme and $2 \cdot 1 \pm 0 \cdot 2 \mu \mathrm{mol} / \mathrm{min} \cdot \mathrm{mg}$ enzyme respectively $(P<0 \cdot 001)$.

\section{DISCUSSION}

Members of this laboratory are primarily concerned with investigating the upregulation of prolactin receptors in mammary epithelium. Previous studies have shown that long-term upregulation is a result of increased transcription of the receptor gene (Bolander et al. 1997); however, there is also a rapid component that is independent of gene expression. This acute phase is caused by a redistribution of prolactin receptors from a substantial intracellular reservoir to the cell surface. This migration is induced by cGMP (Bolander 1998).

Cyclic nucleotides have been shown to be involved in the translocation of several receptors and transducing molecules; for example, cAMP has 


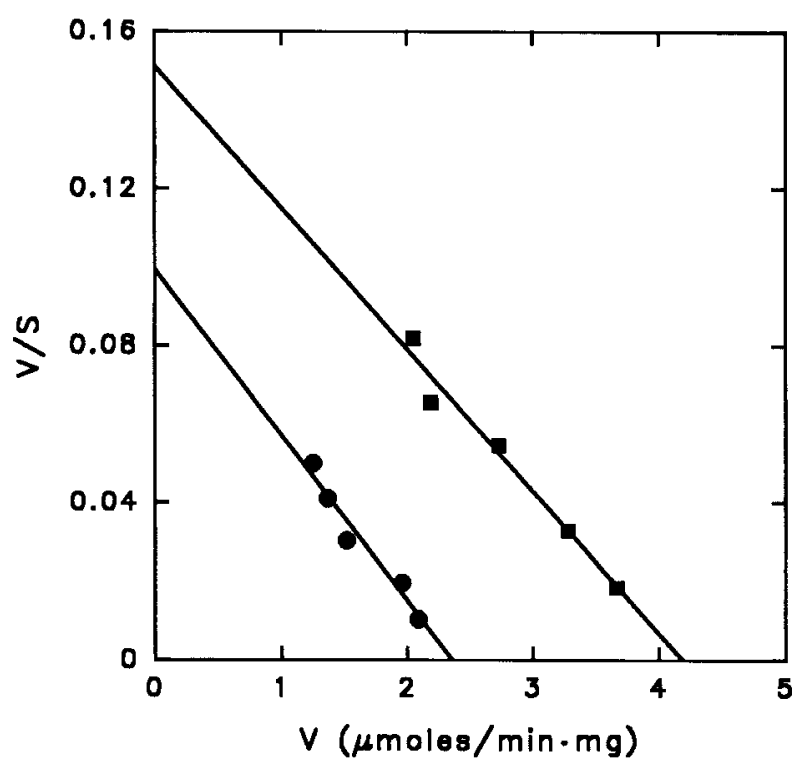

FIGURE 4. Representative Eadie-Hofstee plot of NAG transferase I immunoprecipitated from mammary epithelial cells cultured for $30 \mathrm{~min}$ in the presence $(\boldsymbol{\square})$ or absence ( ) of nitric oxide. The $X$-intercept is $V_{\max }$ and the slope is $-1 / K_{\mathrm{m}} . \mathrm{V}$, initial reaction velocity; $\mathrm{S}$, substrate concentration.

been implicated in the nerve growth factor receptor (Meyer-Franke et al. 1998), the water channel aquaporin-2 (Fushimi et al. 1997), an epithelial chloride channel (Shintani \& Marunaka 1996) and the cystic fibrosis transmembrane conductance regulator (Lehrich et al. 1998). Furthermore, cGMP is involved in the membrane recruitment of the dopamine receptor (Holtbäck et al. 1999). Aquaporin-2 is a direct substrate of the cAMPdependent protein kinase, and its phosphorylation is required for the redistribution of the water channel. However, the prolactin receptor has no consensus sites for PKG within its sequence (Davis \& Linzer 1989, Clarke \& Linzer 1993), therefore the effect of cGMP had to be indirect.

Subsequent studies demonstrated that the prolactin receptors from the internal pool were hypoglycosylated and that cGMP stimulated the maturation of this modification concomitant with translocation. Finally, it was shown that the receptors were arrested at the NAG transferase I step and that cGMP stimulated the activity of this enzyme (Bolander 1999). The present work completes the missing link in this pathway by demonstrating that cGMP increases NAG transferase I activity via PKG phosphorylation.

This method of receptor regulation is rather novel. The requirement for core glycosylation in the

www.endocrinology.org constitutive targeting of receptors to the plasmalemma has been well documented (Collier et al. 1993, Rodríguez et al. 1995, Couvineau et al. 1996, Hall et al. 1997, Buteau et al. 1998). However, the role of terminal glycosylation in the physiological regulation of receptor shuttling is less well studied. In fibroblasts, platelet-derived growth factor increases the receptors for insulin-like growth factor (IGF) by inducing 3-hydroxy-3-methylglutarylcoenzyme A reductase, an enzyme required for the synthesis of the lipid carrier used in core glycosylation. The subsequent availability of this carrier stimulates the $N$-linked glycosylation of the IGF receptor and its appearance at the cell surface (Carlberg \& Larsson 1996, Carlberg et al. 1996). Although this is an example of the transcriptional regulation of core glycosylation, as opposed to the acute regulation of terminal glycosylation, it does demonstrate that physiological systems can use receptor glycosylation as a molecular switch to shuttle proteins to different cellular locations. A potentially more relevant example is found in the intestinal guanylate cyclase $\mathrm{C}(\mathrm{GC}-\mathrm{C})$ receptor, which is predominantly found intracellularly in a hypoglycosylated state during fasting. Feeding leads to both the maturation of glycosylation and the redistribution of GC-C to the cell surface (Scheving et al. 1996). Although the responsible second messenger has not been identified, the fact that the output of $\mathrm{GC}-\mathrm{C}$ is cGMP and that many hormones can recruit their own receptors to the plasmalemma (Holtbäck et al. 1999) suggests that cGMP may be involved.

In summary, this study has shown that an enzyme of terminal glycosylation, NAG transferase I, can be acutely regulated by PKG phosphorylation. Furthermore, this increased activity enhances the capacity of the system to handle proteins such as the prolactin receptor, which are stalled in a hypoglycosylated state under basal conditions.

\section{ACKNOWLEDGEMENT}

The author would like to thank the Monoclonal Antibody Laboratory of the University of South Carolina Institute for Biological Research and Technology for help in generating the polyclonal antibodies to mouse NAG transferase I.

\section{REFERENCES}

Bolander FF 1998 Transduction pathways involved in rapid hormone receptor regulation in the mammary epithelium. American Fournal of Physiology 275 E553-E557.

Bolander FF 1999 Regulation of prolactin receptor glycosylation and its role in receptor location. Molecular and Cellular Endocrinology 149 85-92. 
Bolander FF, Ginsburg E \& Vonderhaar BK 1997 The regulation of mammary prolactin receptor metabolism by a retroviral envelope protein. Fournal of Molecular Endocrinology 19 131-136.

Buteau H, Pezet A, Ferrag F, Perrot-Applanat M, Kelly PA \& Edery M $1998 \mathrm{~N}$-Glycosylation of the prolactin receptor is not required for activation of gene transcription but is crucial for its cell surface targeting. Molecular Endocrinology 12 544-555.

Callsen D, Pfeilschifter J \& Brune B 1998 Rapid and delayed p42/p44 mitogen-activated protein kinase activation by nitric oxide: the role of cyclic GMP and tyrosine phosphatase inhibition. Fournal of Immunology 161 4852-4858.

Carlberg M \& Larsson O 1996 Stimulatory effect of PDGF on HMG-CoA reductase activity and $N$-linked glycosylation contributes to increased expression of IGF-1 receptors in human fibroblasts. Experimental Cell Research 223 142-148.

Carlberg M, Dricy A, Blegen H, Wang M, Hjertman M, Zickert P, Höög A \& Larsson O 1996 Mevalonic acid is limiting for $N$-linked glycosylation and translocation of the insulin-like growth factor-1 receptor to the cell surface: evidence for a new link between 3-hydroxy-3-methylglutarylcoenzyme A reductase and cell growth. Fournal of Biological Chemistry 271 17453-17462.

Clarke DL \& Linzer DIH 1993 Changes in prolactin receptor expression during pregnancy in the mouse ovary. Endocrinology 133 224-232.

Collier E, Carpentier JL, Beitz L, Carol H, Taylor SI \& Gorden P 1993 Specific glycosylation site mutations of the insulin receptor $\alpha$ subunit impair intracellular transport. Biochemistry 32 7818-7823.

Couvineau A, Fabre C, Gaudin P, Maoret JJ \& Laburthe M 1996 Mutagenesis of $N$-glycosylation sites in the human vasoactive intestinal peptide 1 receptor. Evidence that asparagine 58 or 69 is crucial for correct delivery of the receptor to plasma membrane. Biochemistry 35 1745-1752.

Davis JA \& Linzer DIH 1989 Expression of multiple forms of the prolactin receptor in mouse liver. Molecular Endocrinology 3 674-680.

Fushimi K, Sasaki S \& Marumo F 1997 Phosphorylation of serine 256 is required for cAMP-dependent regulatory exocytosis of the aquaporin-2 water channel. Fournal of Biological Chemistry 272 14800-14804.

Hall RA, Hansen A, Andersen PH \& Soderling TR 1997 Surface expression of the AMPA receptor subunits GluR1, GluR2, and GluR4 in stably transfected baby hamster kidney cells. Fournal of Neurochemistry 68 625-630.

Hawkes R, Niday E \& Gordon J 1982 A dot-immunoblotting assay for monoclonal and other antibodies. Analytical Biochemistry 119 142-147.

Ho AK, Hashimoto K \& Chik CL 1999 3',5'-Cyclic guanosine monophosphate activates mitogen-activated protein kinase in rat pinealocytes. Fournal of Neurochemistry 73 598-604.
Holtbäck U, Brismar H, DiBona GF, Fu M, Greengard P \& Aperia A 1999 Receptor recruitment: a mechanism for interactions between $\mathrm{G}$ protein-coupled receptors. Proceedings of the National Academy of Sciences of the USA $967271-7275$.

Laemmli UK 1970 Cleavage of structural proteins during the assembly of the head of bacteriophage T4. Nature 227 680-685.

Lehrich R, Aller SG, Webster P, Marino CR \& Forrest JN 1998 Vasoactive intestinal peptide, forskolin, and genistein increase apical CFTR trafficking in the rectal gland of the spiny dogfish, Squalus acanthias: acute regulation of CFTR trafficking in an intact epithelium. Fournal of Clinical Investigation $101737-745$.

Meyer-Franke A, Wilkinson GA, Kruttgen A, Hu M, Munro E, Hanson MG, Reichardt LF \& Barres BA 1998 Depolarization and cAMP elevation rapidly recruit TrkB to the plasma membrane of CNS neurons. Neuron 21 681-693.

Ono M \& Oka T 1980 The differential actions of cortisol on the accumulation of $\alpha$-lactalbumin and casein in midpregnant mouse mammary gland in culture. Cell 19 473-480.

Pownall S, Kozak CA, Schappert K, Sarkar M, Hull E, Schachter H \& Marth JD 1992 Molecular cloning and characterization of the mouse UDP- $N$-acetylglucosamine: $\alpha$ 3-D-mannoside $\beta-1,2-N$-acetylglucosaminyltransferase I gene. Genomics 12 699-704.

Rodríguez CG, Cundell DR, Tuomanen EI, Kolakowski LE, Gerard C \& Gerard NP 1995 The role of $N$-glycosylation for functional expression of the human platelet-activating factor receptor: glycosylation is required for efficient membrane trafficking. Fournal of Biological Chemistry 270 25178-25184.

Scheving LA, Russell WE \& Chong KM 1996 Structure, glycosylation, and localization of rat intestinal guanylyl cyclase C: modulation by fasting. American Fournal of Physiology 271 G959-G968.

Schillace RV \& Scott JD 1999 Organization of kinases, phosphatases, and receptor signaling complexes. Fournal of Clinical Investigation 103 761-765.

Schmidt HHHW, Lohmann SM \& Walter U 1993 The nitric oxide and cGMP signal transduction system: regulation and mechanism of action. Biochimica et Biophysica Acta 1178 153-175.

Shintani Y \& Marunaka Y 1996 Regulation of chloride channel trafficking by cAMP via protein kinase A-independent pathway in A6 renal epithelial cells. Biochemical and Biophysical Research Communications 223 234-239.

Vischer P \& Hughes RC 1981 Glycosyl transferases of babyhamster-kidney (BHK) cells and ricin-resistant mutants. European Fournal of Biochemistry 117 275-284.

Vonderhaar BK, Owens IS \& Topper YJ 1973 An early effect of prolactin on the formation of $\alpha$-lactalbumin by mouse mammary epithelial cells. Fournal of Biological Chemistry 248 $467-471$.

RECEIVED 2 September 1999 